\title{
Contribution of mycorrhizae to sustainable and ecological agriculture: a review
}

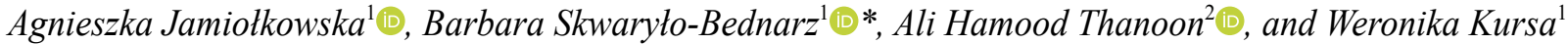 \\ ${ }^{1}$ Department of Plant Protection, University of Life Sciences in Lublin, Leszczyńskiego 7, 20-069 Lublin, Poland \\ ${ }^{2}$ Department of Plant Protection, College of Agriculture and Forestry, University of Mosul, 41002 Mosul, Iraq
}

Received September 2, 2021; accepted November 24, 2021

\begin{abstract}
The aim of the paper is to discuss, on the basis of the recent scientific literature, the potential of mycorrhizae as an important biological factor supporting crop production. Mycorrhizal symbiosis is a multifunctional phenomenon, therefore it should play an important role in sustainable and organic agriculture, but it is still underused. The article focuses on the influence of mycorrhizae on nutrient uptake by plants, as well as exploring the importance of mycorrhizal fungi in promoting plant growth and improving yield quality. Mycorrhizal fungi are factors which limit plant stresses, thereby indirectly contributing to a reduction in the consumption of agrochemicals. The results of many studies show that mycorrhizal symbiosis plays an important role in essential ecosystem processes by regulating the microbiological relationships in the soil, thereby creating a permanent soil structure and protecting it from air and water erosion. The detailed functioning and regulation of these mycorrhizosphere processes and their significance for plants are widely described in the scientific literature, however, the use of mycorrhizae in agriculture is still insufficient. Particular attention should be paid to the potential benefits of mycorrhizae in sustainable agriculture, as well as for ecological and safe plant production.

Keywords: sustainable agriculture, mycorrhiza, ecology plant diseases, plant toxicity
\end{abstract}

\section{INTRODUCTION}

Xenobiotic pollutants accumulate in the environment, i.a. as a result of the application of agricultural chemicals. Agrochemicals become a part of the food chain regard-

*Corresponding author e-mail: barbara.skwarylo@up.lublin.pl less of the origin and type of pollutant that enters the soil (Kowalik, 2001). The uncontrolled leakage of contaminants into food poses a great threat to consumer health. Chemicals which are used in agriculture are a significant source of the ecological stresses encountered by plants, as they can block their enzymatic systems, and contribute to physiological changes, which is often associated with tissue and cell death (Saladin and Clément, 2005). Also, pesticide treatment contributes to the development of resistance to pesticides which is harmful to the environment in practice (McDonald and Linde, 2002). It is therefore, an important strategy to promote and implement sustainable or organic farming as a system using environmentally-friendly management techniques, such as the use of mycorrhizal fungi (MF). These are biological agents whose application in sustainable and organic agriculture is becoming increasingly popular (Gosling et al., 2006; Mahmood and Rizvi, 2010). Mycorrhizae play a significant role, especially as factors limiting plant stresses and enhancing crop productivity, thereby indirectly contributing to a reduction in the consumption of agrochemicals and in environmental pollution (Wang et al., 2020). Arbuscular mycorrhizal fungi (AMF) have the potential to become key organisms which could play important roles in sustainable agricultural ecosystems. The external hyphae of fungi penetrate into soils surrounding plant roots (Finlay, 2008), thereby increasing the root

(C) 2021 Institute of Agrophysics, Polish Academy of Sciences 
absorption area 100- and even 1000-fold (Larcher, 1995). Therefore, AMF increases plant nutrient supply and reduces fertilizer requirements (Finlay, 2008). AMF inoculation has the potential to become an important biotechnological tool which could be widely used in the renewal of modern agricultural ecosystems.

\section{PHENOMENON OF MYCORRHIZAE}

Mycorrhizal fungi (MF) are found in almost every terrestrial ecosystem and play an important role in plant growth and essential ecosystem processes (Błaszkowski and Czerniawska, 2011; Jamiołkowska et al., 2018). Many of the mycorrhizal fungi belong to the phylum Glomeromycota and class Glomeromycetes and their classification is based on molecular, biochemical and morphological identification. The initial research carried out by Kamieński in 1881 with Monotropa hypopitys L., showed that fungi growing at the roots are beneficial for plants. In 1885, the botanist Albert Bernhard Frank was the first to describe the symbiotic relationship between a fungus and tree roots (Smith and Read, 2008). Mycorrhizal fungi form symbiotic associations with the roots of many plants. There are several species of mycorrhizal fungi that colonize various types of agricultural plants (Naher et al., 2013). Mycorrhizae are classified into two main types, namely ectomycorrhiza (intercellular) and endomycorrhiza (intracellular). The second type is divided into ericoid, orchid and a ubiquitous vesicular-arbuscular mycorrhiza (Smith and Read, 2008).

Ectomycorrhizal fungi hyphae form a sheath (mantle) around the plant roots and grow into the space of the cortex parenchyma, where they form a structure known as the Hartig net. On the other hand, hyphae growing outside the sheath penetrate the soil, and frequently form synnemata (vegetative parallel-oriented hyphae) or rhizomorphs (mycelial cords of intertwined hyphae) (Tahat et al., 2010). Individual layers of hyphae are specialized in performing protective or conductive functions. Hyphae outside the roots extend the zone of water and mineral (nitrogen, phosphorus, calcium, potassium and microelements) uptake by the plant roots. Ectomycorrhiza is a characteristic of a large number of trees, both Gymnosperms and Angiosperms (the Pinaceae, Myrtaceae, Salicaceae and Fagaceae families) (Taylor and Aleksander, 2005). Many species of coniferous trees, as well as oak, beech and hornbeam form obligatory mycorrhizas with ectomycorrhizal fungi which are necessary for their proper development. Basidiomycota and Ascomycota fungi are partners in the formation of this type of mycorrhiza (Finlay, 2008; Zuccaro et al., 2014). In endotrophic mycorrhizae, fungal hyphae colonize the intercellular space and the cell interior, but a sheath (mantle) is not formed around the roots and single fungal hyphae penetrate into the soil. Arbuscular mycorrhiza are one of the types of endomycorrhizae, formed mainly by fungi from the Glom- eromycetes class. The external structures of arbuscular mycorrhizal fungi (AMF) are resting spores and hyphae which penetrate the soil. Structures on the outer surface of plant roots that were previously identified as vesicles are now considered to be chlamydospores in the formative stage (Finlay, 2008).

Arbuscular mycorrhizal fungi (AMF) are of great importance among the mycorrhizal fungi (Tahat et al., 2010). Arbuscular mycorrhiza form due to a longstanding symbiotic relationship between a small group of soil fungi and the roots of higher plants, which was formed 460 million years ago (Redecker, 2002). AMF occur in a variety of climates and habitats, both in natural ecosystems and in agricultural areas, and are the most prevalent mycorrhizal fungi (Gaur and Adholeya, 2004). These fungi cannot grow and reproduce without a host plant (Kiriachek et al., 2009). Many researchers (Ellouze et al., 2012; Souza et al., 2005) have noted that the development of symbiosis required two stages in the life cycle of the fungus. The asymbiotic phase begins with spore germination and is particularly dependent on favourable environmental conditions such as appropriate moisture, temperature, and $\mathrm{pH}$ levels, mineral nutrients, organic matter, soil microorganisms and the accumulation of pollutants (Jamiołkowska et al., 2018). The symbiotic phase begins when the fungal mycelium makes physical contact with the root surface and the appressorium differentiates. AM symbiosis is very beneficial for the host plant and enhanced nutrient uptake is the most commonly reported advantage (Hodge and Fitter, 2010). The general life cycle begins with the colonization of a root and the development of arbuscules from the branch hyphae within the root. The development of mycorrhizal symbiosis requires two stages for the completion of the fungus life cycle. The asymbiotic phase begins with the germination of spores and depends on the biotic and abiotic conditions of the environment (humidity, temperature, $\mathrm{pH}$, level of minerals, organic matter, soil microorganisms, pollution level). The symbiotic phase begins when physical contact is made with the root surface, when the extraradical hyphae differentiate into the apressorium. Symbiotic AMF can form extraradical mycelium that grows outside the roots in order to have access to more water and soil minerals for the host plants (Smith and Smith, 2011). The AMF network spreads in the soil and contributes to soil aggregate formation as well as increases in the capture area for inorganic nutrients (Augé, 2001, Brundrett, 2004). The beneficial effect of AMF on soil structure is related to the presence of glomalins. These abundant soil proteins, produced by AMF, have a positive effect on the soil structure by inducing and increasing the stability of soil aggregates, which improves the effectiveness of the symbiotic relationship (Gałąka and Gawryjołek, 2015). 
Table 1. Effect of mycorrhizal fungi (MF) on the plant growth

\begin{tabular}{|c|c|c|}
\hline Influence on & Plant & Reference \\
\hline \multicolumn{3}{|r|}{ Mycorrhizal fungi } \\
\hline $\begin{array}{l}\text { Nutrient } \\
\text { uptake }\end{array}$ & $\begin{array}{l}\text { pepper, } \\
\text { tomato, } \\
\text { cereals }\end{array}$ & $\begin{array}{l}\text { Al-Karaki et al., 2001; Azcón et al., 2001; Hodge et al., 2001; Liu et al., 2002; Giri and Mukerji, } \\
\text { 2004; Govindarajulu et al., 2005; Reynolds et al., 2005; Lambers et al., 2008; Oseni et al., 2010; } \\
\text { Wu et al., 2010; Cavagnaro and Martin, 2011; Guru et al., 2011; Alvarez et al., 2012; Tanwar et } \\
\text { 2013; Motha et al., 2014; Saia et al., 2014; Wahb-Allah et al., 2014; Hart et al., 2015; Michałojć } \\
\text { al., 2015; Chitarra et al., 2016; Jamiołkowska et al., 2020a }\end{array}$ \\
\hline Photosynthesis & $\begin{array}{l}\text { maize, } \\
\text { tomato, } \\
\text { poplar }\end{array}$ & $\begin{array}{l}\text { Augé, 2001; Nelson and Achar, 2001; Sannazzaro et al., 2006; Colla et al., 2008; Zuccarini and } \\
\text { Okurowska, 2008; Sheng et al., 2008; Zhu et al., 2012; Liu et al., } 2015\end{array}$ \\
\hline
\end{tabular}

Claroideoglomus etunicatum and Rhizophagus intraradices

Growth tomato, Augé, 2001; Dasgan et al., 2008; Oseni et al., 2010; Guru et al., 2011; Castillo et al., 2013; olive Conversa et al., 2013; Tanwar et al., 2013; Khabou et al., 2014; Motha et al., 2014; Wahb-Allah et al., 2014

Yield tomato Demir, 2004; Subramanian et al., 2006; Utkhede, 2006; Dasgan et al., 2008; Nzanza et al., 2012; Salvioli et al., 2012; Candido et al., 2013; Colella et al., 2014; Jamiołkowska et al., 2020b

\section{MYCORRHIZAE AND PLANT GROWTH REGULATION}

Mycorrhizae affect several aspects of the plant growth of host plants (physiology, phytopathology, biochemistry). MF directly and indirectly affects plant nutrition, which is reflected in the economic benefits to agricultural systems (Smith and Smith, 2012). At present, a significant volume of research is underway which is focused on the importance of MF in promoting the growth of plants through root colonization and plant nutrition (Table 1). MF protect plants from diseases and toxins and play other roles such as facilitating soil aggregation, plant protection against drought stress and soil pathogens, as well as increasing plant diversity (Whipps, 2004; Zadehbagheri et al., 2014). The best known role of MF is plant stimulation through allowing the plant to obtain microelements from the soil solution via external hyphae and to translocate them to the host through the hyphae, while in return the fungus receives photosynthetic carbonate compounds (Smith and Read, 2008; Santander and Olave, 2012). The degree of plant growth change associated with arbuscular mycorrhizal (AM) colonization may be expressed in terms of mycorrhizal dependency (MD). Tawaraya (2003) reported that the differences in MD between plant species or cultivars depends on many factors, including the plant species or cultivar and fungal species under consideration as well as the soil P levels. The mean values of MD were $44 \%$ for field crops, $56 \%$ for forage crops, $70 \%$ for wild grasses and phorbs, $79 \%$ for trees, and $56 \%$ for all plants, thereby indicating that the cultivated plant species showed a lower MD than the wild plant species. MD was negatively correlated with root morphological characteristics such as root length, root dry weight, root hair length, density of the root hairs, the ability of roots to acquire phosphate from the soil, and the phosphorus utilization efficiency of the host plant.
Recent studies have confirmed the significant impact of MF on the development and growth of various types of vegetables (Table 1). MF influences plant structure in different ways, this is due to the functional diversity of MF (Smith and Read, 2008). This positive effect is associated with the role of MF in increasing the uptake of nutrients and subsequent water absorption leading to better plant growth (Augé, 2001). The application of MF at the initial stage of plant development promotes the symbiosis of AM, which in turn contributes to the improvement in plant growth parameters both in the nursery and in the field (Wang et al., 2008). This hypothesis was confirmed by Jamiołkowska et al. (2008), who showed that the inoculation of seedlings with mycorrhizal fungi significantly influenced the length of tomato stems and roots. It was found that MF application to tomato roots significantly improves the physiological and morphological parameters of the cultivated plants (Jamiołkowska et al., 2020a). Thicker leaves allow for improved photosynthesis at a high radiation intensity, which explains the high variation of this feature in response to light. A thicker epidermis is a mechanical barrier to pathogens infecting plants, and the predisposition of the host plant to form physical structures preventing the spread of pathogens is important for plant resistance (Poorter et al., 2010).

The application of MF is beneficial for plants and results in a better uptake of immobilized phosphate ions. Phosphorus is an essential macronutrient and plays an important role in all biological systems, as it participates in all energy transfer processes in the form of ATP and is an essential component of various biological molecules (nucleotides, phospholipids and sugar phosphates). One of the significant advantages of using mycorrhiza is the increase in the phosphorus nutrition of the plants during cultivation. Phosphorus captured from the rhizosphere is 
absorbed by AMF hyphae and then absorbed and transported along the hyphae to the interior of the mycelium and finally to the cortical region of the roots (Alvarez et al., 2012). The increased uptake of other macro- and micronutrients (potassium, nitrogen, calcium, copper, sulphur, zinc, iron, magnesium) after MF application was also observed (Table 1). The inoculation of plants with MF was demonstrated to have a positive effect on the quality of plant fruit (Nzanza et al., 2012; Jamiołkowska et al., 2020a). Michałojć et al. (2015) found that the fruit of plants inoculated with mycorrhizal fungi had a high level of calcium as compared to the control plants. Increased $\mathrm{K}, \mathrm{Ca}$ and $\mathrm{Mg}$ uptake by inoculated plants may occur through two mechanisms; the first one involves direct nutrient capture by extraradical mycorrhizal hyphae, thereby increasing the absorption of the root systems, which shortens the nutrient transport distance in the soil before they reach the roots. It has been shown that the direct uptake and transport of $\mathrm{K}$ and $\mathrm{Ca}$ to the plant occurs through AMF extraradical hyphae (George, 2000). The second mechanism that may be responsible for the increased content of these ingredients in mycorrhizal plants is increased water uptake, which results in the improved flow of macronutrients from the soil (Khalvati et al., 2005). Mycorrhizal plants can extract more water from the soil and have a higher root hydraulic conductivity, thereby improving the water absorption rate of the plants, and reducing the response to drought stress. Mycorrhiza can also regulate the selectivity of the root plasma membrane towards water, with enhanced P-nutrition, which increases the resistance of crops to drought. In the event of water stress, AMF increases the rate of transpiration and stomatal conductance or it modifies the equilibrium of plant hormones (Junqin et al., 2019). The major factors causing increased water transport and reduced resistance to water through-flow with mycorrhizal inoculation may be the increased root surface area provided by the hyphae (Allen, 1982). The high levels of macronutrients in plants inoculated with MF may be due to the higher rate of photosynthesis in mycorrhizal plants (Nelson and Achar, 2001). The improved acquisition of phosphate from the soil and the improvement in the nutritional status of plants, is one of the reasons for the effective impact of mycorrhization on tomato productivity (Subramanian et al., 2006). The distribution of carbon in various parts of the plant, the supply of plant nutrients, as well as tolerance and resistance to heavy metals in the soil depend on the degree of root colonization by endomycorrhizal fungi, which change both the quantity and quality of the host plant's root exudates (Tahat and Sijam, 2012).

Plant mycorrhization increases the content of chlorophyll in plants (Sannazzaro et al., 2006; Sheng et al., 2008; Manila and Nelson, 2014). Elevated chlorophyll content is directly correlated with the photosynthetic rate in mycorrhizal plants (Ratti et al., 2010). Chlorophyll fluorescence is a parameter used to analyse the photosynthetic process and related mechanisms in plants that grow under stress conditions (Hussain and Reigosa, 2011; Qiu et al., 2013). Some studies have shown that AM symbiosis improved the $\mathrm{Fv} / \mathrm{Fm}$ ratio in maize leaves (Sheng et al., 2008; Zuccarini and Okurowska, 2008; Zhu et al., 2012). Liu et al. (2015) found that MF increased the drought tolerance of poplar by reducing the decrease in photosynthesis parameters such as Fv/Fm and qP. Mycorrhizal plants also showed more active non-photochemical quenching than the non-inoculated plants (Sheng et al., 2008).

Better growth and a higher yield of tomatoes inoculated with MF have been confirmed in numerous studies (Table 1). Michałojć et al. (2015) however did not confirm this hypothesis because no beneficial effect of AMF on the yield of tomato grown in rockwool and straw was noted. These studies show that MF can develop and form a symbiosis with plants growing in natural soil and not in an artificial substrate such as mineral wool. Other studies conducted on tomato plants grown in a field and inoculated with a commercial AMF formulation showed larger inflorescences and a higher number of flowers as well as a higher total and marketable yield as compared to non-inoculated plants (Conversa et al., 2013). A study of Jamiołkowska et al. (2020) showed no significant effect of MF (Claroideoglomus etunicatum and Rhizophagus intraradices) on the total and marketable yield of tomato, but rather demonstrated the effect of mycorrhizae on reducing the number of diseased fruits.

In addition to these advantages, arbuscular mycorrhiza (AM) provides plants with other benefits, such as improved disease resistance (Pozo and Azcón-Aguilar, 2007). MF show some similarity to biotrophic pathogens and are able to induce plant defence reactions in the initial stages of symbiosis (Paszkowski, 2006; Jung et al., 2012). For colonization to be successful, the fungus has to modulate these plant responses. This modulation may pre-condition the tissues for the efficient activation of plant defences in the event of a pathogen attack ("priming" phenomenon) (Pozo and Azcón-Aguilar, 2007). Song et al. (2015) found that mycorrhization enhanced tomato resistance to Alternaria solani infection by priming the systemic defence response (jasmonic acid signalling pathway). AMF increases plant resistance to various phytopathogens (Harrier and Watson, 2004; Pozo et al., 2005; Bi et al., 2007). The appropriate management of AMF may be applied to ensure the sustainability of agricultural systems in relation to plant disease management (Liu et al., 2007).

\section{MF EFFECT ON PLANT HEALTH STATUS}

Mycorrhizal fungi (MF) are used in biological plant protection to reduce the development of pests, especially pathogens. In recent years, many studies have investigated the ability of AMF to limit the development of diseases caused by soil-borne pathogens (Matloob and Juber, 2013; 
Kareem and Hassan, 2014). Plant mycorrhization and related changes in the roots as well as the activation of plant defence mechanisms contributes to the reduction of disease severity (Demir and Akköprü, 2005). The potential of MF to control phytopathogenic fungi has been described by many scientists (Table 2). Mycorrhized plants are less susceptible to pathogens. Several studies have reported the beneficial effect of MF inoculation on plant health status and the reduction in pathogen development. MF inhibits infection and the development of many soil-borne pathogens, such as Fusarium species, Verticillium spp., Rhizoctonia solani, Pythium ultimum and Phytophthora species, however, effective biocontrol has also been observed against phyllosphere pathogenic fungi such as Alternaria solani (Table 2). Fritz et al. (2006) found that the protective effect of mycorrhiza against the development of tomato leaf spots (A. solani) occurred in parallel to the induced systemic resistance. Mycorrhizal networks formed between tomato seedlings to protect neighbouring plants from early blight (Song et al., 2015). Jamiołkowska et al. (2020) also demonstrated the beneficial effects of AMF (C. etunicatum and $R$. intraradices) on the health status of tomato, where the DI (disease index) depended not only on the tomato cultivars, but also on the fungus species used for mycorrhization.

The effect of Glomus spp. application on plant root protection has been described by many researchers (Table 2). The effectiveness of inoculation and MF persistence depends on several factors in the soil (temperature, soil moisture, soil phosphorus content, mycorrhizal fungus species, mycorrhizal inoculation time, mycorrhizal inoculum level and pathogen inoculum potential) (Berruti et al., 2015; Jamiołkowska et al., 2018). Yao et al. (2002) demonstrated that inoculation with MF reduced $R$. solani development on micropropagated potato plantlets. In the present study, AMF ( $R$. intraradices and $C$. etunicatum) were used against the soil pathogen of tomato, i.e. Fusarium spp. Both biocontrol agents were particularly effective at inhibiting root rot diseases (Ozgonen et al., 2001; Berta et al., 2005). The species composition of the fungal populations of plants are modified not only by AMF treatment, but also by other microorganisms in the rhizosphere that interact with key AMF components of the soil microbiota (Jamiołkowska et al., 2020b). In this context, AM formation changes the plant physiology and the nutritional and physical properties of rhizosphere soil. In this way, AMF interacts with microorganisms in the rhizosphere, thereby affecting both soil properties and quality. Conversely, soil organisms also significantly affect AM development and functioning (Barea et al., 2002). Changes within a population also depend on the interaction of fungi in a given community. The study allowed for the determination of the influence of $R$. intraradices and C. etunicatum on the development of Colletotrichum coccodes on tomato (Jamiołkowska et al., 2020a) and included the application of AMF which reduced the occurrence of $C$. coccodes on potato plants (Cwalina-Ambroziak et al., 2015). Therefore, AMF may be recommended to protect tomatoes against root anthracnose. AMF creates favourable conditions for the activity of rhizosphere microorganisms. Matsubara et al. (2010) suggested that Glomus intraradices is an effective biocontrol agent for Fusarium crown and root rot which may appear in degraded soil. The improvement of plant health status also depends on the composition of the microbiota in the plant rhizosphere. MF influences the development and activity of soil microorganisms (Jamiołkowska et al., 2020b). MF application (i.e. Claroideoglomus etunicatum) on tomato roots contributes to an increase in the number of soil fungi, especially saprotrophs in the rhizosphere. The symbiosis between MF and the plant may also be promoted by soil microorganism exudates, especially certain saprophytic bacteria and fungi (mycorrhizal helper bacteria) (Joseph and Sivaprasad, 2000). Studies conducted by Jamiołkowska

Table 2. Effect of mycorrhizal fungi (MF) on the plant health status

\begin{tabular}{|c|c|c|}
\hline Influence on & Plant & Reference \\
\hline \multicolumn{3}{|r|}{ Mycorrhizal fungi } \\
\hline $\begin{array}{l}\text { Verticillium } \\
\text { dahliae }\end{array}$ & cotton & Zhang et al., 2018 \\
\hline Fusarium spp. & $\begin{array}{l}\text { tomato, bean, chry- } \\
\text { santhemum, cucumber, } \\
\text { chickpea }\end{array}$ & $\begin{array}{l}\text { Bhagawati et al., 2000; Siddiqui and Singh, 2004; Akköprü and Demir, 2005; Hao et } \\
\text { al., 2005; Al-Askar and Rashad, 2010; Matsubara et al., 2010; Manila and Nelson, } \\
\text { 2014; Al-Hmoud and Al-Momany, 2015; Jamiołkowska et al., 2020a }\end{array}$ \\
\hline Phytophthora spp. & tobacco & Trotta et al., 1996; Pozo et al., 2002 \\
\hline \multicolumn{3}{|c|}{ Claroideoglomus etunicatum, Rhizophagus intraradices, Funneliformis mosseae, Rhizophagus irregularis, Glomus spp. } \\
\hline Other pathogens & $\begin{array}{l}\text { banana, cucumber, } \\
\text { tomato, cotton, potato, } \\
\text { sweet pepper }\end{array}$ & $\begin{array}{l}\text { Becker et al., 1999; Declerck et al., 2002; Berta et al., 2005; Kobra et al., 2009; } \\
\text { Bødker et al., 2002; Kasiamdari et al., 2002; Yao et al., 2002; Harrier and Watson, } \\
\text { 2004; Whipps, 2004; Pozo and Azcón-Aguilar, 2007; Matsubara et al., 2010; Died- } \\
\text { hiou et al., 2013; Matloob and Juber, 2013; Manila and Nelson, 2014; Cwalina- } \\
\text {-Ambroziak et al., 2015; Al-Hmoud and Al-Momany, 2015; Song et al., 2015; } \\
\text { Jamiołkowska et al., 2020b }\end{array}$ \\
\hline
\end{tabular}


et al. (2020b) show that in mycorrhizal plants, the fungal biodiversity increases within the rhizosphere (a greater number of saprotrophic fungi with antagonistic abilities).

\section{SOIL CONTAMINATION AND MYCORRHIZAE}

MF can be used in agricultural cultivation systems to reduce the application of synthetic fertilizers, pesticides and other supplements, thereby enhancing crop quality (Bhattacharyya and Jha, 2012) and stimulating contaminant bioremediation (Gaur and Adholeya, 2004; Fester, 2013). Overall, MF reduces organic contaminant residues in the aboveground part of plants, but causes an increased accumulation of contaminants, especially persistent organic pollutants (POPs) in plant roots (Wang et al., 2020). MF also have a significant potential in the restoration of degraded soils with low fertility without losses in productivity (Quilambo, 2003). Mycorrhizal fungi are present on the roots of plants growing in heavy metal contaminated soils and play an important role in metal tolerance and accumulation. MF play a significant role in the phytostabilization of toxic compounds. Mycorrhizal plants accumulate metallic pollutants by storing these heavy metals in vesicles and in fungal hyphae in their roots, due to this, the contaminants are immobilized in the fungal structures and do not inhibit nutrient uptake. MF releases glomalins, which are metal-absorbing glycoproteins and thus immobilize toxic metals. Another protein is metallothionin which is released by some MF, this also reduces the toxicity of heavy metals in the soil (copper, cadmium, zinc, lead). AMF reduces the toxicity of heavy metals by metabolizing these metals. Metallothionins like polypeptides are known to cause heavy metal detoxification in AM fungal cells. Mycorrhizal fungi also induce plant resistance to salinity stress and they can be extremely beneficial in the phytoremediation of the soil (Bano and Ashfag, 2013). The isolation of native and stress-adapted AMF species could be a potential biotechnology tool for inoculating plants in order to successfully restore degraded ecosystems or convert conventional farms to organic ones (Gaur and Adoleya, 2004).

\section{CONCLUSIONS AND PROSPECTS FOR FUTURE}

Mycorrhizal fungi (MF) interact with the most cultivated plants, such as cereals, vegetables and fruit trees, and are receiving increasing attention due to their potential use in sustainable and organic plant production. Studies concerning the effects of MF on plant growth and crop productivity have led to several hypotheses (Elmer, 2002), among which the most important are: improvements in nutrition resulting in better plant growth, higher plant resistance to pathogen contamination or symptom compensation, plant morphological changes (structural barrier formation), changes in the biochemical compounds related to plant defence and an increase in the percentage of antagonists in the mycorrhi- zosphere. Not only can MF improve soil fertility and plant health, but it can also alter the accumulation of contaminants in plants. The benefits and mechanisms behind the role of MF in alleviating biotic and abiotic stresses, in organic and sustainable farming, are as follows: 1) increased plant biomass through improved mineral plant nutrition and water soil distribution, 2) reducing the infestation of plants by pests, 3) reducing the oxidative stress induced by soil contaminants, 4) the accumulation and sequestration of contaminants by AMF structures, 5) stimulating the development of antagonistic microorganisms in the soil and ensuring the microbiological balance of the rhizosphere, 6) improving soil structure, and 7) reducing pesticide application due to increased crop resistance to pathogens and improving the competitive position of plants with regard to weeds.

Studies conducted with AMF in recent years have revealed their myriad benefits for plant health, soil and crop productivity. Therefore, it is believed that AMF could be used as bio-fertilizers in the near future to improve soil fertility, as well as plant growth and development. AMF can serve as a substitute for inorganic fertilizers, increasing the bioavailability of minerals, especially phosphorus. It is believed that AMF can reduce the use of chemical fertilizers by up to $50 \%$ in order to obtain better agricultural production, depending on the crop species and prevailing stress factors (Begum et al., 2019). Moreover, mycorrhizae, due to their ability to bind heavy metals, can be used to improve the quality of degraded soils (Asmelash et al., 2016). Therefore, it is important to characterize the native AMF population specific to the soils of a geographical area in order to create effective compositions (AMF consortium inocula) of autochthonous mycorrhizal fungal species which effectively enhance crop productivity and remediate degraded soils. This is a challenge not only for scientists but also for biotechnologists to develop fungal inocula for large-scale applications.

Conflict of interest: The authors declare no conflict of interest.

\section{REFERENCES}

Akköprü A. and Demir S., 2005. Biological control of Fusarium wilt in tomato caused by Fusarium oxysporum f. sp. lycopersici by AMF Glomus intraradices and some rhizobacteria. J. Phytopathol., 153(9), 544-555. https://doi.org/10.1111/j.1439-0434.2005.01018.x

Al-Askar A.A. and Rashad Y.M., 2010. Arbuscular mycorrhizal fungi: A biocontrol agent against common bean Fusarium root rot disease. Plant Pathol. J., 9, 31-38. https://doi.org/10.3923/ppj.2010.31.38

Al-Hmoud G. and Al-Momany A., 2015. Effect of four mycorrhizal products on Fusarium root rot on different vegetable crops. J. Plant Pathology Microbiol., 6(2), 1. https://doi.org/10.4172/2157-7471.1000255 
Allen F.M., 1982. Influence of vesicular-arbuscular mycorrhiza on water movement though Bouteloua gracilis (H.B.K) Lag ex Steud. New Phytol., 92, 191-196.

https://doi.org/10.1111/j.1469-8137.1982.tb03305.x

Al-Karaki G. N., Hammad R., and Rusan M., 2001. Response of two tomato cultivars differing in salt tolerance to inoculation with mycorrhizal fungi under salt stress. Mycorrhiza, 11(1), 43-47. https://doi.org/10.1007/s005720100098

Alvarez M., Huygens D., Diaz L.M., Villanueva C.A., Heyser W., and Boeckx P., 2012. The spatial distribution of acid phosphatase activity in ectomycorrhizal tissues depends on soil fertility and morphotype, and relates to host plant phosphorus uptake. Plant Cell Environ., 35(1), 126-135. https:// doi.org/10.1111/j.1365-3040.2011.02422.x

Asmelash F., Bekele T., and Birhane E., 2016. The potential role of arbuscular mycorrhizal fungi in the restoration of degraded land. Front. Microbiol., 7, 1095. https://doi.org/10.3389/ fmicb.2016.01095

Augé R.M., 2001. Water relations, drought and vesicular-arbuscular mycorrhizal symbiosis. Mycorrhiza, 11(1), 3-42. https://doi.org/10.1007/s005720100097

Azcón R., Ruiz-Lozano J.M., and Rodriguez R., 2001. Differential contribution of arbuscular mycorrhizal fungi to plant nitrate uptake $\left({ }^{15} \mathrm{~N}\right)$ under increasing $\mathrm{N}$ supply to the soil. Can. J. Bot., 79(10), 1175-1180. https://doi.org/10.1139/b01-093

Bano S.A. and Ashfaq D., 2013. Role of mycorrhiza to reduce heavy metal stress. Nat. Sci., 5(12A), 16-20. https://doi. org/10.4236/ns.2013.512A003

Barea J.M., Toro M., Orozco M.O., Campos E., and Azcón R., 2002. The application of isotopic $\left({ }^{32} \mathrm{P}\right.$ and $\left.{ }^{15} \mathrm{~N}\right)$ dilution techniques to evaluate the interactive effect of phosphatesolubilizing rhizobacteria, mycorrhizal fungi and Rhizobium to improve the agronomic efficiency of rock phosphate for legume crops. Nutrient Cycling Agroecosys., 63(1), 35-42.

Bhattacharyya P.N. and Jha D.K., 2012. Plant growth-promoting rhizobacteria (PGPR): emergence in agriculture. World J. Microbiol. Biotechnol., 28, 1327-1350. https://doi.org/10.1007/s11274-011-0979-9

Becker D.M., Bagley S.T., and Podila G.K., 1999. Effects of mycorrhizal-associated streptomycetes on growth of Laccaria bicolor, Cenococcum geophilum, and Armillaria species and on gene expression in Laccaria bicolor. Mycologia, 33-40. https://doi.org/10.1080/00275514.1999. 12060991

Begum N., Qin C., Ahanger M.A., Raza S., Khan M.I., Ashraf M., Ahmed N., and Zhang L., 2019. Role of arbuscular mycorrhizal fungi in plant growth regulation: implications in abiotic stress tolerance. Front. Plant Sci., 10. 1068. https://doi.org/10.3389/fpls.2019.01068

Berruti A., Lumini E., Balestrini R., and Bianciotto V., 2015. Arbuscular mycorrhizal fungi as natural biofertilizers: Let's benefit from past successes. Front Microbiol., 6, 1559. https://doi.org/10.3389/fmicb.2015.01559

Berta G., Sampo S., Gamalero E., Massa N., and Lemanceau P., 2005. Suppression of Rhizoctonia root-rot of tomato by Glomus mossae BEG12 and Pseudomonas fluorescens A6RI is associated with their effect on the pathogen growth and on the root morphogenesis. Eur. J. Plant Pathol., 111(3), 279-288. https://doi.org/10.1007/s10658-004-4585-7

Bhagawati B., Goswami B.K., and Singh C.S., 2000.
Management of disease complex of tomato caused by Meloidogyne incognita and Fusarium oxysporum f. sp. lycopersici through bioagent. Indian J. Nematol., 30(1), 16-21.

Bi H.H., Song Y.Y., and Zeng R.S., 2007. Biochemical and molecular responses of host plants to mycorrhizal infection and their roles in plant defence. Allelopathy J., 20(1), 15.

Blaszkowski J. and Czerniawska B., 2011. Aarbuscular mycorrhizal fungi (Glomeromycota) associated with roots of Ammophila arenaria growing in maritime dunes of Bornholm (Denmark). Acta Societatis Botanicorum Poloniae, 80, 1, 63-76. https://doi.org/10.5586/asbp.2011.009

Bødker L., Kjøller R., Kristensen K., and Rosendahl S., 2002. Interactions between indigenous arbuscular mycorrhizal fungi and Aphanomyces euteiches in field-grown pea. Mycorrhiza, 12(1), 7-12.

https://doi.org/10.1007/s00572-001-0139-4

Brundrett M., 2004. Diversity and classification of mycorrhizal associations. Biol. Rev. Camb. Philos. Soc., 79(3), 473-495. https://doi.org/10.1017/S1464793103006316

Candido V., Campanelli G., D'Addabbo T., Castronuovo D., Renco M., and Camele I., 2013. Growth and yield promoting effect of artificial mycorrhization combined with different fertiliser rates on field-grown tomato. Italian J. Agron., 8(3), 22. https://doi.org/10.4081/ija.2013.e22

Castillo C., Morales A., Rubio R., and Barea J.M., 2013. Interactions between native arbuscular mycorrhizal fungi and phosphate solubilizing fungi and their effect to improve plant development and fruit production by Capsicum annuum L. Afr. J. Microbiol. Res., 7(26), 3331-3340. https://doi. org/10.5897/AJMR2012.2363

Cavagnaro T.R. and Martin A.W., 2011. Arbuscular mycorrhizas in southeastern Australian processing tomato farm soils. Plant and Soil, 340(1-2), 327-336. https://doi.org/10.1007/ s11104-010-0603-z

Chitarra W., Pagliarani C., Maserti B., Lumini E., Siciliano I., Cascone P., Schubert A., Gambino G., Balestrini R., and Guerrieri E., 2016. Insights on the impact of arbuscular mycorrhizal symbiosis on tomato tolerance to water stress. Plant Physiology, 171, 1009-1023. https://doi.org/10.1104/ pp.16.00307

Colella T., Candido V., Campanelli G., Camele I., and Battaglia D., 2014. Effect of irrigation regimes and artificial mycorrhization on insect pest infestations and yield in tomato crop. Phytoparasitica, 42(2), 235. https://doi.org/10.1007/ s12600-013-0356-3

Colla G., Rouphael Y., Cardarelli M., Tullio M., Rivera C.M., and Rea E., 2008. Alleviation of salt stress by arbuscular mycorrhizal in zucchini plants grown at low and high phosphorus concentration. Biol. Fertil. Soils, 44(3), 501-509. https://doi.org/10.1007/s00374-007-0232-8

Conversa G., Lazzizera C., Bonasia A., and Elia A., 2013. Yield and phosphorus uptake of a processing tomato crop grown at different phosphorus levels in a calcareous soil as affected by mycorrhizal inoculation under field conditions. Biol. Fertil. Soils, 49(6), 691.

https://doi.org/10.1007/s00374-012-0757-3

Cwalina-Ambroziak B., Damszel M.M., and Głosek-Sobieraj M., 2015. The effect of biological and chemical control 
agents on the health status of the very early potato cultivar Rosara. J. Plant Prot. Res., 55(4), 389-395. https://doi. org/10.1515/jppr-2015-0052

Dasgan H.Y., Kusvuran S., and Ortas I., 2008. Responses of soilless grown tomato plants to arbuscular mycorrhizal fungal (Glomus fasciculatum) colonization in re-cycling and open systems. Afr. J. Biotechnol., 7(20), 3606-3613.

Declerck S., Risede J.M., Rufyikiri G., and Delvaux B., 2002. Effects of arbuscular mycorrhizal fungi on severity of root rot of bananas caused by Cylindrocladium spathiphylli. Plant Pathol., 51(1), 109-115. https://doi.org/10.1046/j.0032-0862.2001.656.x

Demir S., 2004. Influence of arbuscular mycorrhiza on some physiological growth parameters of pepper. Turk. J. Biol., 28, 85-90.

Demir S. and Akköprü A., 2005. Using of arbuscular mycorrhizal fungi (AMF) for biocontrol of soil-borne fungal pathogens. In: Biological control of plant diseases: current concepts (Eds S.B. Chincholkar, K.G. Mukerji). Howarth Press, NY, USA, 17-46.

Diedhiou P.M., Hallmann J., Oerke E.C., and Dehne H.W., 2003. Effects of arbuscular mycorrhizal fungi and a nonpathogenic Fusarium oxysporum on Meloidoyne incognita infestation of tomato. Mycorrhiza, 13,199-204. https://doi. org/10.1007/s00572-002-0215-4

Ellouze W., Hamel C., Freire Cruz A., Ishii T., Gan Y., Bouzid S., and St-Arnaud M., 2012. Phytochemicals and Spore Germination: At the Root of AMF Host Preference? Appl. Soil Ecol., 60, 98-104. https://doi.org/10.1016/j.apsoil.2012.02.004

EImer W.H., 2002. Influence of formononetin and $\mathrm{NaCl}$ on mycorrhizal colonization and Fusarium crown and root rot of asparagus. Plant Disease, 86, 1318-1324. https://doi. org/10.1094/PDIS.2002.86.12.1318

Fester T., 2013. Arbuscular mycorrhizal fungi in a wetland constructed for benzene-, methyl tert-butyl ether- and ammonia-contaminated groundwater bioremediation. Microb. Biotechnol., 1, 80-84. https://doi.10.1111/j.1751-7915.2012.00357.x

Finlay R.D., 2008. Ecological aspects of mycorrhizal symbiosis: with special emphasis on the functional diversity of interactions involving the extraradical mycelium. J. Exp. Bot., 59, 1115-1126. https://doi.org/10.1093/jxb/ern059

Fritz M., Jakobsen I., Lyngkjær M. F., Thordal-Christensen H., and Pons-Kühnemann J., 2006. Arbuscular mycorrhiza reduces susceptibility of tomato to Alternaria solani. Mycorrhiza, 16, 413-419. https://doi.org/10.1007/s00572-006-0051-z

Gałązka A. and Gawryjołek K., 2015. Glomalin - soil glicoprotein produced by arbuscular mycorhizal fungus (in Polish). Post. Microbiol., 54, 4, 331-343.

Gaur A. and Adholeya A., 2004. Prospects of arbuscular mycorrhizal fungi in phytoremediation of heavy metal contaminated soils. Curr. Sci., 86, 528-534.

George E., 2000. Nutrient uptake. Contributions of arbuscular mycorrhizal fungi to plant mineral nutrition. In: Arbuscular mycorrhizas: physiology and function (Eds Y. Kapulnik, D.D. Douds). Kluwer Academic, The Netherlands, 307343. https://doi.org/10.1007/978-94-017-0776-3_14

Giri B. and Mukerji K.G., 2004. Mycorrhizal inoculant alleviates salt stress in Sesbania aegyptiaca and Sesbania grandiflora under field conditions: evidence for reduced sodium and improved magnesium uptake. Mycorrhiza, 14(5), 307-312. https://doi.org/10.1007/s00572-003-0274-1

Gosling P., Hodge A., Goodlass G., and Bending G.D., 2006. Arbuscular mycorrhizal fungi and organic farming. Agric. Ecosyst. Environ., 113, 17-35. https://doi.org/10.1016/j. agee.2005.09.009

Govindarajulu M., Pfeffer P.E., Jin H.R., Abubaker J., Douds D.D., and Allen J.W., 2005. Nitrogen transfer in the arbuscular mycorrhizal symbiosis. Nature, 435, 819-823. https:// doi.org/10.1038/nature03610

Guru V., Tholkappian P., and Viswanathan K., 2011. Influence of arbuscular mycorrhizal fungi and Azospirillum co-inoculation on the growth characteristics, nutritional content, and yield of tomato crops grown in south India. Indian J. Fundamental Applied Life Sci., (JLS), 1(4), 84-92. http:// www.cibtech.org/jls.htm

Hao Z., Christie P., Qin L., Wang C., and Li X., 2005. Control of Fusarium wilt of cucumber seedlings by inoculation with an arbuscular mycorrhizal fungus. J. Plant Nutr., 28(11), 1961-1974. https://doi.org/10.1080/01904160500310997

Harrier L.A. and Watson C.A., 2004. The potential role of arbuscular mycorrhizal (AM) fungi in the bioprotection of plants against soil-borne pathogens in organic and/or other sustainable farming systems. Pest Manag. Sci., 60(2), 149157. https://doi.org/10.1002/ps. 820

Hart M., Ehret D.L., Krumbein A., Leung C., Murch S., Turi C., and Franken P., 2015. Inoculation with arbuscular mycorrhizal fungi improves the nutritional value of tomatoes. Mycorrhiza, 25, 359-376. https://doi.org/10.1007/ s00572-014-0617-0

Hodge A., Campbell C.D., and Fitter A.H., 2001. An arbuscular mycorrhizal fungus accelerates decomposition and acquires nitrogen directly from organic material. Nature, 413(6853), 297-299. https://doi.org/10.1038/35095041

Hodge A. and Fitter A.H., 2010. Substantial nitrogen acquisition by arbuscular mycorrhizal fungi from organic material has implications for N cycling. Proc. National Academy Sci. USA, 107, 13754-13759.

https://doi.org/10.1073/pnas.1005874107

Hussain M.I. and Reigosa M.J., 2011. A chlorophyll fluorescence analysis of photosynthetic efficiency, quantum yield and photon energy dissipation in PSII antennae of Lactuca sativa L. leaves exposed to cinnamic acid. Plant Physiol. Biochem., 49(11), 1290-1298. https://doi.org/10.1016/j. plaphy.2011.08.007

Jamiołkowska A., Księżniak A., Gałązka A., Hetman B., Kopacki M., and Skwaryło-Bednarz B., 2018. Impact of abiotic factors on development of the community of arbuscular mycorrhizal fungi in the soil. Int. Agrophys., 32, 133-140. https://doi.org/10.1515/intag-2016-0090

Jamiołkowska A., Thanoon A.H., Skwaryło-Bednarz B., Patkowska E., and Mielniczuk E., 2020a. Mycorrhizal inoculation as an alternative for the ecological production of tomato (Lycopersicon esculentum Mill.). Int. Agrophys., 34(2), 253-264. https://doi.org/10.31545/intagr/118196

Jamiołkowska A., Skwaryło-Bednarz B., Patkowska E., Buczkowska H., Gałązka A., Grządziel J., and Kopacki M., 2020b. Effect of mycorrhizal inoculation and irrigation 
on biological properties of sweet pepper rhizosphere in organic field cultivation. Agronomy-Basel, 1693. https:// doi.org/10.3390/agronomy10111693

Joseph P.J. and Sivaprasad P., 2000. The potential of arbuscular mycorrhizal associations for biocontrol of soil-borne diseases. Springer Science and Business Media LLC: New York, NY, USA https://doi.org/10.1007/978-1-4615-4209-4_10

Jung S.C., Martinez-Medina A., Lopez-Raez J.A., and Pozo M.J., 2012. Mycorrhiza-induced resistance and priming of plant defenses. J. Chem. Ecol., 38(6), 651-664. https://doi. org/10.1007/s10886-012-0134-6

Junqin L., Meng B., Chai H., Yang X. Song W., Li S., Lu A., Zhang T., and Sun W., 2019. Arbuscular mycorrhizal fungi alleviate drought stress in $\mathrm{C}_{3}$ (Leymus chinensis) and $\mathrm{C}_{4}$ (Hemarthria altissima) grasses via altering antioxidant enzyme activities and photosynthesis. Front. Plant Sci., 10, 499. https://doi.org/10.3389/fpls.2019.00499

Kareem T.A. and Hassan M.S., 2014. Evaluation of Glomus mosseaeas biocontrol agents against Rhizoctonia solani on tomato. J. Biol. Agric. Healthc., 4(2), 15-19.

Kasiamdari R.S., Smith S.E., Smith F.A., and Scott E.S., 2002. Influence of the mycorrhizal fungus, Glomus coronatum, and soil phosphorus on infection and disease caused by binucleate Rhizoctonia and Rhizoctonia solani on mung bean (Vigna radiata). Plant Soil, 238(2), 235-244. https:// doi.org/10.1023/A:1014400701819

Khabou W., Hajji B., Zouari M., Rigane H., and Abdallah F.B., 2014. Arbuscular mycorrhizal fungi improve growth and mineral uptake of olive tree under gypsum substrate. Ecol. Eng., 73, 290-296.

https://doi.org/10.1016/j.ecoleng.2014.09.054

Khalvati M.A., Hu Y., Mozafar A., and Schmidhalter U., 2005. Quantification of water uptake by arbuscular mycorrhizal hyphae and its significance for leaf growth, water relations, and gas exchange of barley subjected to drought stress. Plant Biol. (Stuttg), 7(6), 706-12. https://doi.org/10.1055/s-2005-872893

Kiriachek S.G., Azevedo L.B.C., Peres L.E.P., and Lambais M.R., 2009. Regulation of arbuscular mycorrhizae development (in Spanish). Rev. Bras. Ciênc. Solo, 33(1). https:// doi.org/10.1590/S0100-06832009000100001

Kobra N., Jalil K., and Youbert G., 2009. Effects of three Glomus species as biocontrol agents against Verticilliuminduced wilt in cotton. J. Plant Prot. Res., 49(2), 185-189. https://doi.org/10.2478/v10045-009-0027-z

Kowalik P., 2001. Pesticides as a source of pollution (in Polish). Wyd. PWN, Warsaw, Poland.

Lambers H., Raven J.A., Shaver G.R., and Smith S.E., 2008. Plant nutrient-acquistion strategies change with soil age. Trends in Ecol. Evolution (TREE), 23(2), 95-103. https:// doi.org/10.1016/j.tree.2007.10.008

Larcher W., 1995. Physiological Plant Ecology. Berlin: SpringerVerlag. https://doi.org/10.1007/978-3-642-87851-0

Liu J., Maldonado-Mendoza I., Lopez-Meyer M., Cheung F., Town C.D., and Harrison M.J., 2007. Arbuscular mycorrhizal symbiosis is accompanied by local and systemic alterations in gene expression and an increase in disease resistance in the shoots. Plant J., 50(3), 529-544. https://doi. org/10.1111/j.1365-313X.2007.03069.x
Liu R., Wang F., and Meng X., 2002. Arbuscular mycorrhizal fungi in the islands of the Bohai bay. Mycosystema, 21(4), $525-532$.

Liu T., Sheng M., Wang C.Y., Chen H., Li Z., and Tang M., 2015. Impact of arbuscular mycorrhizal fungi on the growth, water status, and photosynthesis of hybrid poplar under drought stress and recovery. Photosynthetica, 53(2), 250258. https://doi.org/10.1007/s11099-015-0100-y

Mahmood I. and Rizvi R., 2010. Mycorrhiza and organic farming. Asian J. Plant Sci., 9, 241-248. https://doi.org/10.3923/ ajps.2010.241.248

Manila S. and Nelson R., 2014. Biochemical changes induced in tomato as a result of arbuscular mycorrhizal fungal colonization and tomato wilt pathogen infection. Asian J. Plant Sci. Res., 4(1), 62-68.

Matloob A.A.H. and Juber K.S., 2013. Biological control of bean root rot disease caused by Rhizoctonia solani under green house and field conditions. Agric. Biol. J. North America, 4(5), 512-519. http://www.scihub.org/ABJNA

Matsubaraa Y., Okada T., and Nahiyan A.S.M., 2010. Tolerance to allelopathy and Fusarium disease, changes in antioxidant substance in mycorrhizal asparagus plants raised in decline soil. Acta Hortic., 883, 417-423. https://doi.org/10.17660/ ActaHortic.2010.883.52

McDonald B. and Linde C., 2002. Pathogen population genetics, evolutionary potential, and durable resistance. Annu. Rev. Phytopathol., 40(1), 349-379. https://doi.org/10.1146/ annurev.phyto.40.120501.101443

Michałojć Z., Jarosz Z., Pitura K., and Dzida K., 2015. Effect of mycorrhizal colonization and nutrient solutions concentration on the yielding and chemical composition of tomato grown in rockwool and straw medium. Acta Sci. Pol. Hortorum Cultus, 14, 15-27.

Motha S.V., Hindumathi A., and Bhumi N.R., 2014. Influence of arbuscular mycorrhizal fungi on plant growth promotion and biological control of Verticillium wilt of tomato (Lycopersicon esculentum). Int. J. Pharma Bio Sci., 5(4): B1000-B1009.

Naher U.A., Othman R., and Panhwar Q.A., 2013. Beneficial effects of mycorrhizal association for crop production in the tropics a review. Int. J. Agric. Biol., 15(5), 1021-1028.

Nelson R. and Achar P.N., 2001. Stimulation of growth and nutrient uptake by VAM fungi in Brassica oleracea var. capitata. Biologia Plantarum, 44(2), 277-281. https://doi. org/10.1023/A:1010211711882

Nzanza B., Marais D., and Soundy P., 2012. Effect of arbuscular mycorrhizal fungal inoculation and biochar amendment on growth and yield of tomato. Int. J. Agric. Biol., 14, 965969. http://hdl.handle.net/2263/20948

Oseni T.O., Shongwe N.S., and Masarirambi M.T., 2010. Effect of arbuscular mycorrhiza (AM) inoculation on the performance of tomato nursery seedlings in vermiculite. Int. J. Agric. Biol., 12, 789-792.

Ozgonen H., 2001. The effect of salicylic acid and endomycorrhizal fungus Glomus etunicatum on plant development of tomato and Fusarium wilt caused by Fusarium oxysporum f. sp. lycopersici. Turkish J. Agric. Forest., 25, 25-29.

Paszkowski U., 2006. Mutualism and parasitism: The yin and yang of plant symbioses. Curr. Opin. Plant Biol., 9(4), 364370. https://doi.org/10.1016/j.pbi.2006.05.008 
Poorter H., Niinemets Ü., Walter A., Fiorani F., and Schurr U., 2010. A method to construct dose-response curves for a wide range of environmental factors and plant traits by means of a meta-analysis of phenotypic data. J. Exp. Bot., 61(8), 2043-2055. https://doi.org/10.1093/jxb/erp358

Pozo M.J. and Azcón-Aguilar C., 2007. Unraveling mycorrhizainduced resistance. Curr. Opin. Plant Biol. 10(4), 393-398. https://doi.org/10.1016/j.pbi.2007.05.004

Pozo M.J., Cordier C., Dumas-Gaudot E., Gianinazzi S., Barea J.M., and Azcón-Aguilar C., 2002. Localized versus systemic effect of arbuscular mycorrhizal fungi on defence responses to Phytophthora infection in tomato plants. J. Exp. Bot., 53(368), 525-34. https://doi.org/10.1093/jexbot/53.368.525

Pozo M.J., Van Loon L.C., and Pieterse C.M.J., 2005. Jasmonates-signals in plant-microbe interactions. J. Plant Growth Regul., 23(3), 211-222. https://doi.org/10.1007/ s00344-004-0031-5

Qiu Z., Wang L., and Zhou Q., 2013. Effects of bisphenol A on growth, photosynthesis and chlorophyll fluorescence in above-ground organs of soybean seedlings. Chemosphere, 90(3), 1274-1280.

https://doi.org/10.1016/j.chemosphere.2012.09.085

Quilambo O.Q., 2003. The vesicular-arbuscular mycorrhizal symbiosis. Afr. J. Biotechnol., 2(12), 539-546. https://doi. org/10.5897/AJB2003.000-1105

Ratti N., Verma H.N., Gautam S.P., 2010. Effect of Glomus species on physiology and biochemistry of Catharanthus roseus. Indian J. Microbiol., 50(3), 355-60. https://doi. org/10.1007/s12088-010-0012-2

Redecker D., 2002. Molecular identification and phylogeny of arbuscular mycorrhizal fungi. Plant Soil, 244(1), 67-73. https://doi.org/10.1023/A:1020283832275

Reynolds H.L., Hartley A.E., Vogelsang K.M., Bever J.D., and Schultz P.A., 2005. Arbuscular mycorrhizal fungi do not enhance nitrogen acquisition and growth of old-field perennials under low nitrogen supply in glasshouse culture. New Phytologist, 167(3), 869-880. https://doi.org/10.1111/j.1469-8137.2005.01455.x

Saia S., Amato G., Frenda A.S., Giambalvo D., and Ruisi P., 2014. Influence of arbuscular mycorrhizae on biomass production and nitrogen fixation of berseem clover plants subjected to water stress. PLoS One, 9(3), e90738. https:// doi.org/10.1371/journal.pone.0090738

Saladin G. and Clément C., 2005. Physiological side effects of pesticides on non-target plants. In: Agriculture and Soil Pollution (Ed. J.V. Livingston). Nova Science Publishers, Inc., Hauppauge, NY, USA.

Salvioli A., Zouari I., Chalot M., and Bonfante P., 2012. The arbuscular mycorrhizal status has an impact on the transcriptome profile and amino acid composition of tomato fruit. BMC Plant Biology, 12(1), 44. https://doi.org/10.1186/1471-2229-12-44

Sannazzaro A.I., Ruiz O.A., Albertó E.O., and Menéndez A.B., 2006. Alleviation of salt stress in Lotus glaber by Glomus intraradices. Plant Soil, 285(1), 279-287. https://doi.org/10.1007/s11104-006-9015-5

Santander C. and Olave J., 2012. Effect of symbiosis in the production of melon seedlings with arbuscular mycorrhizal fungi. IDESIA (Chile), 30(2), 75-83. https://doi.org/10.4067/S0718-34292012000200010
Sheng M., Tang M., Chen H., Yang B., Zhang F., and Huang Y., 2008. Influence of arbuscular mycorrhizae on photosynthesis and water status of maize plants under salt stress. Mycorrhiza, 18(6), 287-296.

https://doi.org/10.1007/s00572-008-0180-7

Siddiqui Z.A. and Singh L.P., 2004. Effects of soil inoculants on the growth, transpiration and wilt disease of chickpea. J. Plant Dis. Prot., 111, 2, 151-157. https://doi.org/10.1007/ BF03356141

Smith S.E. and Read D.J., 2008. Mineral nutrition, toxic element accumulation and water relations of arbuscular mycorrhizal plants. In: Mycorrhizal Symbiosis (Eds S. Smith, D. Read). Academic Press, 145-187. https://doi.org/10.1016/B978-012370526-6.50007-6

Smith S.E. and Smith F.A., 2011. Roles of arbuscular mycorrhizas in plant nutrition and growth: new paradigms from cellular to ecosystems scales. Annu. Rev. Plant Biol., 62, 227-250. https://doi.org/10.1146/annurev-arplant-042110-103846

Smith S.E. and Smith F.A., 2012. Fresh perspectives on the roles of arbuscular mycorrhizal fungi in plant nutrition and growth. Mycologia, 104(1), 1-13. https://doi.org/10.3852/11-229

Song Y., Chen D., Lu K., Sun Z., and Zeng R., 2015. Enhanced tomato disease resistance primed by arbuscular mycorrhizal fungus. Front. Plant Sci., 6, 786. https://doi.org/10.3389/ fpls.2015.00786

Souza F.A., Dalpé Y., Declerck S., Providencia I.E., and Séjalon-Delmas N., 2005. Life history strategies in Gigasporaceae. Insight from monoxenic culture. In: In vitro culture of Mycorrhizas (Eds S. Declerck, D. G. Strullu, J.A. Fortin). Heidelberg, Germany: Springer-Verlag, 73-91. https://doi. org/10.1007/3-540-27331-X_5

Subramanian K.S., Santhanakrishnan P., and Balasubramanian P., 2006. Responses of field grown tomato plants to arbuscular mycorrhizal fungal colonization under varying intensities of drought stress. Scientia Horticulturae, 107(3), 245-253. https://doi.org/10.1016/j.scienta.2005.07.006

Tahat M.M., Kumaruzaman S., and Othman R., 2010. Mycorrhizal fungi as a biocontrol agent. Plant Pathol. J., 9(4), 198-207. https://doi.org/10.3923/ppj.2010.198.207

Tahat M.M. and Sijam K., 2012. Arbuscular mycorrhizal fungi and plant root exudates bio-communications in the rhizosphere. Afr. J. Microbiol. Res., 6(46), 7295-7301. https://doi. org/10.5897/AJMR12.2250

Tanwar A., Aggarwal A., Kadian N., and Gupta A., 2013. Arbuscular mycorrhizal inoculation and super phosphate application influence plant growth and yield of Capsicum annuum. J. Soil Sci. Plant Nutr., 13(1), 55-66. https://doi. org/10.4067/S0718-95162013005000006

Tawaraya K., 2003. Arbuscular mycorrhizal dependency of different plant species and cultivars. Soil Sci. Plant Nutr., 49, 5, 655-668. https://doi.org/10.1080/00380768.2003.104 10323

Taylor A.F.S. and Alexander I., 2005. The ectomycorrhizal symbiosis: life in the real world. Mycologist, 1993, 102-112. https://doi.org/10.1017/S0269-915X(05)00303-4

Trotta A., Varese G.C., Gnavi E., Fusconi A., Sampò S., and Berta G., 1996. Interactions between the soilborne root pathogen Phytophthora nicotinae var. parasitica and the 
arbuscular mycorrhizal fungus Glomus mosseae in tomato plants. Plant Soil, 185(2), 199-209. https://doi.org/10.1007/ BF02257525

Utkhede R., 2006. Increased growth and yield of hydroponically grown greenhouse tomato plants inoculated with arbuscular mycorrhizal fungi and Fusarium oxysporum f. sp. radicislycopersici. Biocontrol, 51(3), 393-400. https://doi.org/10.1007/s10526-005-4243-9

Wahb-Allah M., Abdel-Razzak H., Aslsdon A., and Ibrahim A., 2014. Growth, yield, fruit quality and water use efficiency of tomato under arbuscular mycorrhizal inoculation and irrigation level treatments. Life Sci. J., 11, 109-117.

Wang C., Li X., Zhou J., Wang G., and Dong Y., 2008. Effects of arbuscular mycorrhizal fungi on growth and yield of cucumber plants. Commun. Soil Sci. Plant Anal., 39(3-4), 499-509. https://doi.org/10.1080/00103620701826738

Wang F., Adams C.A., Yang W., Sun Y., and Shi Z., 2020. Benefits of arbuscular mycorrhizal fungi in reducing organic contaminant residues in crops: Implications for cleaner agricultural production. Crit. Rev. Environ. Sci. Technol., 50(15), 1580-1612. https://doi.org/10.1080/10643389.2019. 1665945

Whipps J.M., 2004. Prospects and limitations for mycorrhizas in biocontrol of root pathogens. Can. J. Bot., 82, 1198-1227. https://doi.org/10.1139/b04-082

Wu Q.S., Zou Y.N., Liu W., Ye X.F., Zai H.F., and Zhao L.J., 2010. Alleviation of salt stress in citrus seedlings inoculated with mycorrhiza: changes in leaf antioxidant defense systems. Plant Soil Environ., 56(10), 470-475. https://doi. org/10.17221/54/2010-PSE
Yao M., Tweddell R., and Desilets H., 2002. Effect of two vesicular-arbuscular mycorrhizal fungi on the growth of micropropagated potato plantlets and on the extent of disease caused by Rhizoctonia solani. Mycorriza, 12, 235-242. https://doi.org/10.1007/s00572-002-0176-7

Zadehbagheri M., Azarpanah A., and Javanmardi S., 2014. Perspective of arbuscular mycorrhizal fungi phytoremediation on contamination and remediation heavy metals soil in sustainable agriculture. American-Eurasian J. Agric. Environ. Sci., 14(4), 379-386. https://doi.10.5829/idosi. aejaes.2014.14.04.12320

Zhang Q., Gao X., Ren Y., Ding X., Qiu J., Li N., Zeng F., and Chu Z., 2018. Improvement of Verticillium Wilt resistance by applying arbuscular mycorrhizal fungi to a cotton variety with high symbiotic efficiency under field conditions. Int. J. Mol. Sci., 19(1), 241. https://doi.org/10.3390/ijms19010241

Zhu X.C., Song F.B., Liu S.Q., Liu T.D., and Zhou X., 2012. Arbuscular mycorrhizae improves photosynthesis and water status of Zea mays L. under drought stress. Plant Soil Environ., 58(4), 186-191. https://doi.org/10.17221/23/2011-PSE

Zuccarini P. and Okurowska P., 2008. Effects of mycorrhizal colonization and fertilization on growth and photosynthesis of sweet basil under salt stress. J. Plant Nutr., 31(3), 497513. https://doi.org/10.1080/01904160801895027

Zuccaro A., Lahrmann U., and Langen G., 2014. Broad compatibility in fungal root symbioses. Curr. Opin. Plant Biol., 20, 135-145. https://doi.org/10.1016/j.pbi.2014.05.013 